\title{
Expansive soil improvement of Glagahagung village, Purwoharjo sub-district, Banyuwangi district, which is chemically stabilized
}

\author{
Paksitya Purnama Putra ${ }^{1,}$, Diah Ayu Paramiswari ${ }^{1}$, Abdullah Ilham $^{1}$, and M. Farid Ma'ruf ${ }^{1}$ \\ ${ }^{1}$ University of Jember, Civil Engineering Department, Jember - Jawa Timur, Indonesia
}

\begin{abstract}
Expansive soil can be easily found at Purwoharjo, a sub-district of Banyuwangi. Swelling and shrinkage behavior of the soil is usually referred to by the local community as a "moving soil" phenomenon. It causes cracks on a number of buildings which is a major issue in that area. Various methods of expansive soil stabilization are available. This work intends to lay comparisons on stabilizations using wood charcoal powder and salt. The stabilizing materials are mixed with the soils under different proportion. Volume weight, index properties, and dry density are parameters to be investigated during the stabilization process. The results show that salt stabilized expansive soil is better than wood charcoal powder. $15 \%$ proportion of salt to soils weight increases the density by about $20 \%$. Meanwhile, the stabilized soil is as a result of change to low plasticity silt (ML) from previously high plasticity soil (CH) of the original one.
\end{abstract}

\section{Preliminary}

Purwoharjo District Chief Secretary stated that about 80 percent of the land condition of its territory, is "moving soil". Villagers believe that this "moving soil" is the source of their homes often being damaged. In civil engineering, "moving soil" is often referred to as expansive soil. The expansive soil has high shrinkage properties, and its behavior is highly influenced by water. The soil that has excessive swell-shrinkage fluctuations is called expansive soil [3]. Expansive soils can indeed impact damage to buildings due to the outrageous shrinking properties as a result of fluctuation in the quantity of water it holds. Expansive soil will expand if the water content increases, and on the other hand, will shrink when the water content decreases. Damages triggered by high expansivity can be seen from the cracks in the foundations, floors, and walls of buildings. The expansion and shrinking process of expansive soil are influenced by environmental factors, including climate change, rainfall, drainage and fluctuation of groundwater [3].

\footnotetext{
* Corresponding author: paksitya.putra@yahoo.com
} 
In this research, the process of soil improvement is implemented through chemical stabilization. Chemical stabilizing materials employed are, wood charcoal, and salt. From some of these stabilizing materials, changes before and after being given stabilizers will be compared. The optimum condition of the percentage of the use of each stabilizing material will also be known. The best stabilizing material recommendations for the use of some of these stabilizers are also indicated. Therefore, people can choose the stabilizing material according to their needs.

\section{Research method}

Stages of research conducted are structured as follows:

\subsection{Preparation}

Preparation stage is conducted to obtain primary and secondary data. Primary data includes: location survey, soil sampling, taking and testing chemical elements of stabilizing materials. Secondary data covers literature studies and previous studies.

Based on the results of laboratory testing, chemical elements of natural soil, wood charcoal powder, and salt can be seen in the Table 1 and Table 2 as follows:

Table 1. Chemical elements of a natural soil-based laboratory test.

\begin{tabular}{|c|c|}
\hline $\begin{array}{c}\text { Chemical } \\
\text { elements }\end{array}$ & $\begin{array}{c}\text { Result } \\
\text { (\%) }\end{array}$ \\
\hline $\mathrm{SiO}_{2}$ & 65.52 \\
\hline $\mathrm{Al}_{2} \mathrm{O}_{3}$ & 15.23 \\
\hline $\mathrm{Fe}_{2} \mathrm{O}_{3}$ & 11.88 \\
\hline $\mathrm{MgO}$ & 1.21 \\
\hline $\mathrm{CaO}$ & 0.32 \\
\hline
\end{tabular}

Table 2. Chemical elements of a wood charcoal powder-based laboratory test.

\begin{tabular}{|c|c|}
\hline $\begin{array}{c}\text { Chemical } \\
\text { elements }\end{array}$ & $\begin{array}{c}\text { Result } \\
\text { (\%) }\end{array}$ \\
\hline $\mathrm{C}$ & 22.83 \\
\hline $\mathrm{SiO}_{2}$ & 12.53 \\
\hline $\mathrm{Al}_{2} \mathrm{O}_{3}$ & 8.21 \\
\hline $\mathrm{Fe}_{2} \mathrm{O}_{3}$ & 0.87 \\
\hline $\mathrm{MgO}$ & 0.35 \\
\hline $\mathrm{CaO}$ & 0.32 \\
\hline $\mathrm{P}_{2} \mathrm{O}_{5}$ & 0.15 \\
\hline
\end{tabular}

The wood charcoal consists of carbon $(\mathrm{C}$. Therefore if it reacts with silica ( $\mathrm{Si}$ ) which is present in soil and water $\left(\mathrm{H}_{2} \mathrm{O}\right)$ it will produce carbon dioxide $\left(\mathrm{CO}_{2}\right)$ illustrated in the formulation as follows [4]:

$$
\mathrm{SiO}_{2}+\mathrm{C}+\mathrm{H}_{2} \mathrm{O} \rightarrow \mathrm{Si}+\mathrm{CO}_{2}+\mathrm{H}_{2} \mathrm{O}
$$

Whereas, when the element of silica $(\mathrm{Si})$ reacts with salt $(\mathrm{NaCl})$ and water $\left(\mathrm{H}_{2} \mathrm{O}\right)$, it will produce $\mathrm{Na}_{2} \mathrm{SiO}_{3}$ and ${ }_{2} \mathrm{HCl}$ as in the formulation below [5]:

$$
\mathrm{SiO}_{2}+{ }_{2} \mathrm{NaCl}+\mathrm{H}_{2} \mathrm{O} \rightarrow \mathrm{Na}_{2} \mathrm{SiO}_{3}+{ }_{2} \mathrm{HCL}
$$


So, it can be concluded that charcoal wood and salt can react chemically, with the production of new gases and compounds of the existing elements.

To measure the level of expansivity, several methods are implemented based on the soil plasticity properties that have been expressed by some experts. Such can be seen in Table 3 to Table 6, and Fig 1 below:

- SNI 03-6795-2002

Table 3. Expansive soil criteria based on SNI 03-6795-2002 [2].

\begin{tabular}{|c|c|c|c|}
\hline Swelling Level & $\begin{array}{c}\text { Liquid Limit } \\
\mathbf{\%}\end{array}$ & $\begin{array}{c}\text { Plasticity Index } \\
\mathbf{\%}\end{array}$ & $\begin{array}{c}\text { Suction test } \\
\mathbf{( k N / m 2 )}\end{array}$ \\
\hline High & $>60$ & $>35$ & $>4$ \\
\hline Medium & $50-60$ & $25-35$ & $1,5-4$ \\
\hline Low & $<50$ & $<25$ & $<1,5$ \\
\hline
\end{tabular}

- Chen (1988)

Table 4. Expansive soil criteria based on plasticity index [1].

\begin{tabular}{|c|c|}
\hline Plasticity Index \% & Swelling Potential \\
\hline $0-15$ & Low \\
\hline $10-35$ & Medium \\
\hline $25-35$ & High \\
\hline$>35$ & Very High \\
\hline
\end{tabular}

- Snethen (1977)

Table 5. Classification of potential expands [1].

\begin{tabular}{|c|c|c|c|c|}
\hline LL (\%) & PI (\%) & Sat Tsf & $\begin{array}{c}\text { Potential Swelling } \\
(\%)\end{array}$ & $\begin{array}{c}\text { Potential Swelling } \\
\text { Classification }\end{array}$ \\
\hline$>60$ & $>35$ & $>4$ & $>1,5$ & High \\
\hline $50-60$ & $25-35$ & $1,5-4$ & $0,5-1,5$ & Medium \\
\hline$<50$ & $<25$ & $<1,5$ & $<0,5$ & Low \\
\hline
\end{tabular}

- Seed (1962)

Table 6. Classification of expansive degree [1].

\begin{tabular}{|c|c|}
\hline $\begin{array}{c}\text { Potential Swelling } \\
(\mathbf{\%})\end{array}$ & Swelling Degree \\
\hline $0-1,5$ & Low \\
\hline $1,5-5$ & Medium \\
\hline $5-25$ & High \\
\hline$>25$ & Very High \\
\hline
\end{tabular}




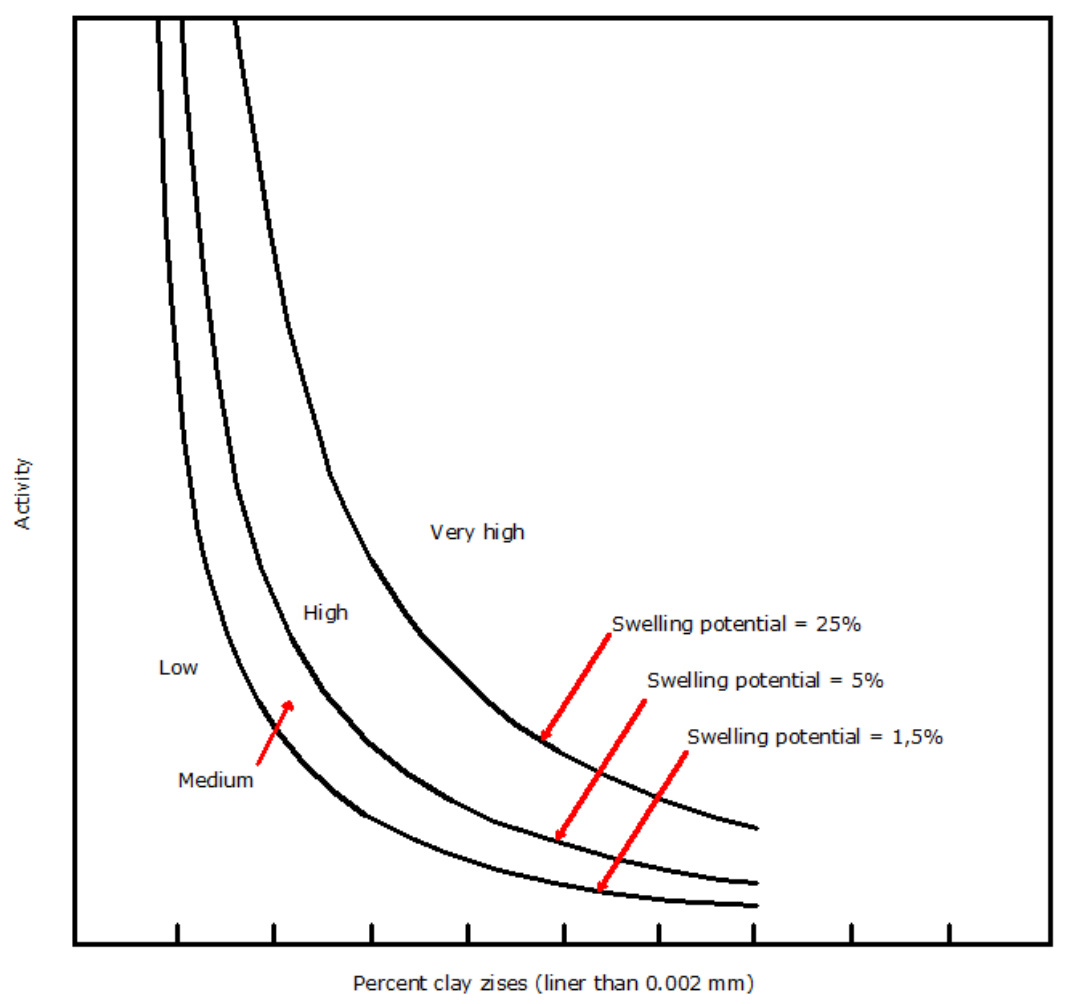

Fig. 1. Classification of potential expands clay [1].

\subsection{Natural soil test}

After obtaining soil samples, undisturbed soils are used for testing the physical and mechanical properties of natural soils. Tests of physical properties carried out are volumetry gravimetry, sieve \& hydrometer analysis, and Atteberg's limits. Tests of mechanical properties performed are standard Proctor test, unconfined compressive strength test, a swelling test-based soil plasticity property.

\subsection{Mixed soil test (natural + stabilizer)}

The mixed soil is a natural soil that has been mixed with a stabilizing material. The optimum moisture content (OMC) of the original soil is used as the initial moisture content of all mixed soils also to be used also in the curing. The percentage of stabilizing materials used in mixed soil is different. The percentage of stabilizing materials is determined based on previous studies [4,5]. The use of various percentages of stabilizers is intended to determine the optimum level of the stabilizing material. Taken from previous researches and logical assumptions, the content of stabilizers for wood charcoal are 5\%, 15\%, 25\%, $35 \%$, and salt, $5 \%, 10 \%, 15 \%, 20 \%, 25 \%$ of natural soil dry weight. After curing, physical and mechanical testing of mixed soil is conducted. 


\section{Discussion}

This study is a laboratory-based research, so all the majority of data obtained is primary data. These data are physical and mechanical parameter data just as discussed in research methodology. All these data will be analyzed and discussed in this chapter.

\subsection{Preparation results}

The survey of the research sites was conducted to directly review the issues studied. Also, it was essential to request authorization from the relevant village officials regarding the research. Based on direct interviews from several village officials, and villagers, it is said that they have problems with their home conditions, which are frequently damaged (cracked walls, broken floors, broken columns, etc.) yearly. Villagers assume that it is an outcome of "moving land" which in technical language is called expansive ground. Based on direct field observations, the damage occurring to the villagers' houses did show to be a result of expansive land as shown in Figure 2 below.

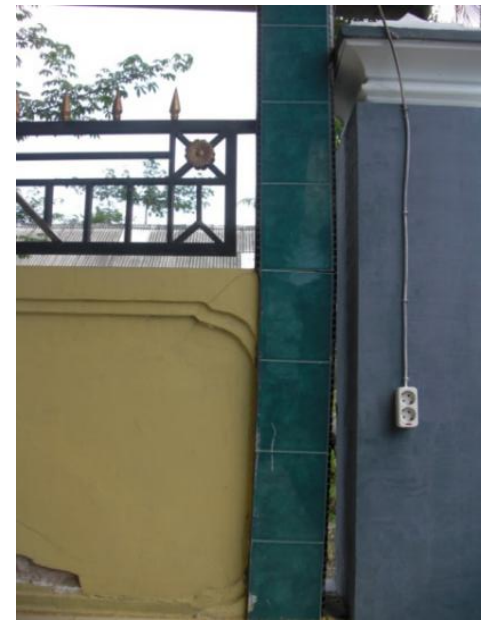

(a)

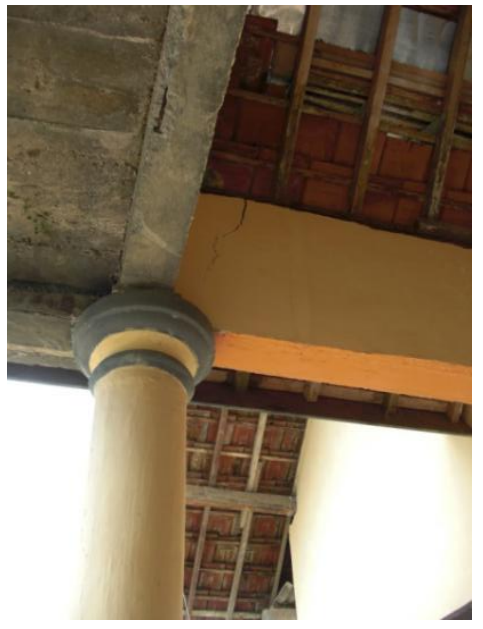

(b)

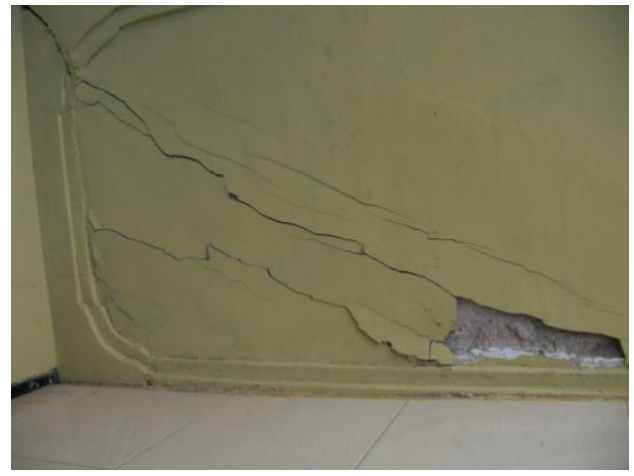

(c)

Fig. 2. Documentation on damage to houses, (a). broken column, (b) broken beam, (c) cracked wall. 
The results of the expansive soil identification of several methods are presented in Table 7 below.

Table 7. Swelling classification of natural soil.

\begin{tabular}{|c|c|c|c|c|c|c|}
\hline \multirow{2}{*}{ Activity } & \multicolumn{2}{|c|}{$\begin{array}{c}\text { Atteberg's } \\
\text { Limits }\end{array}$} & \multicolumn{4}{c|}{ Swelling Criteria } \\
\cline { 2 - 7 } & LL & PI & Chen & Snethen & Seed & $\begin{array}{c}\text { SNI-03-6795- } \\
\text { 2002 }\end{array}$ \\
\hline 1,508 & 90,86 & 53,89 & Very High & High & Very High & High \\
\hline
\end{tabular}

\subsection{Physical parameter result and analysis}

After the soil samples are obtained, the laboratory tests are carried out as described in the previous chapter. Laboratory tests begin with all tests to detect the physical and mechanical parameters of natural soil. The next test is a test to realize the physical and mechanical parameters of the mixed soil (natural soil + stabilizer). All physical parameter test results can be summarized and viewed in table 8 below.

Table 8. Soil properties index test results.

\begin{tabular}{|c|c|c|c|c|c|c|c|c|c|}
\hline \multirow{2}{*}{$\begin{array}{l}\text { Stabili } \\
\text { zer } \\
\text { Type }\end{array}$} & \multirow{2}{*}{$\begin{array}{c}\text { Stabilizer } \\
\text { Percentage } \\
(\%)\end{array}$} & \multirow[b]{2}{*}{$\begin{array}{l}\text { We } \\
(\%)\end{array}$} & \multirow[b]{2}{*}{$\begin{array}{l}\text { LL } \\
(\%)\end{array}$} & \multirow[b]{2}{*}{$\begin{array}{l}\text { PL } \\
(\%)\end{array}$} & \multirow[b]{2}{*}{$\begin{array}{c}\text { IP } \\
(\%)\end{array}$} & \multirow{2}{*}{$\begin{array}{c}\text { Pass } \\
\text { No. } 200 \\
(\%)\end{array}$} & \multirow[b]{2}{*}{ GI } & \multicolumn{2}{|c|}{ Classification } \\
\hline & & & & & & & & AASTHO & $\begin{array}{l}\text { US } \\
\text { CS }\end{array}$ \\
\hline $\begin{array}{c}\text { Natural } \\
\text { Soil }\end{array}$ & 0 & 40.45 & 87.99 & 41.99 & 46.00 & 96.5 & 56.397 & A-7-5 & $\mathrm{CH}$ \\
\hline \multirow{5}{*}{ Salt } & 5 & 37,33 & 90,86 & 36,97 & 53,89 & 96,54 & 35,79 & A-7-6 & $\mathrm{CH}$ \\
\hline & 10 & 31,61 & 58,60 & 36,27 & 22,34 & 81,70 & 8,23 & A-7-6 & $\mathrm{MH}$ \\
\hline & 15 & 30,23 & 44,00 & 28,58 & 15,42 & 91,60 & 4,15 & A-7-6 & ML \\
\hline & 20 & 29,65 & 42,35 & 27,13 & 15,23 & 93,80 & 4,12 & A-7-6 & ML \\
\hline & 25 & 28,11 & 41,00 & 27,02 & 13,98 & 93,80 & 3,14 & A-7-6 & ML \\
\hline \multirow{4}{*}{$\begin{array}{l}\text { Wood } \\
\text { Charco } \\
\text { al }\end{array}$} & 5 & 30.52 & 56.50 & 23.50 & 33.00 & 78.85 & 27.07 & A-7-6 & $\mathrm{CH}$ \\
\hline & 15 & 26.74 & 53.50 & 28.87 & 24.63 & 59.07 & 12.88 & A-7-6 & $\mathrm{CH}$ \\
\hline & 25 & 22.16 & 48.40 & 32.86 & 15.54 & 48.79 & 5.21 & A-7-5 & ML \\
\hline & 35 & 20.20 & 45.25 & 30.05 & 15.20 & 46.93 & 4.36 & A-7-5 & ML \\
\hline
\end{tabular}

Based on the physical test results from the table, the original soil is classified as Clay High $(\mathrm{CH})$ soil in USCS system and A-7-6 in AASHTO system with a water content of $40.45 \%$, liquid limit (LL) of $87.99 \%$, plastic limit of $41.99 \%$, and a plasticity index of $46 \%$. Based on the percentage of pass filter 200 as much as $96.5 \%$, then the original soil is included into the fine-grained soil. High clay type soils have high plasticity, so it can be said that the soil shrink rate is high.

Globally, it can be compared that there is a drastic decline in all parametric values. At the moisture content $(\mathrm{Wc})$, continual addition of stabilizer content will result to a decrease in water content. A very sharp decrease in the liquid limit (LL) is observed in all stabilizer additions. The decrease of the liquid limit occurs to close to $40 \%$, similarly at the plastic limit (PL). Changes in the liquid limit and plastic limit will undoubtedly affect the Plasticity Index (PI). A reduction in the plasticity index indicates a larger grain size change. The larger the grain size, the lesser the cohesion value will decrease. 
Grain size changes can also be seen from the number of percentages that pass filter 200 . All the stabilizer additions to the original soil influence the percentage drop in the number of filters passing through 200. This indicates that the grains contained in the original soil after being mixed with the stabilizer material turned into coarse grains. In salt stabilizers, the increase in percentage of pass filter 200 is more likely to be directly proportional to the increase in the percentage of stabilizer increases. However, the change in grain size can be seen in its fine grain, from clay to silt.

The most glaring increase in grain size can be seen from the soil classification. Natural soils are classified in high clay $(\mathrm{CH})$ in USCS and A-7-5 systems in ASSHTO classification. Based on all the percentages of the addition of stabilizer material, it can be seen that in the USCS classification, there is an increase in grain and a change in plasticity properties from $\mathrm{CH}$ to ML.

Based on all the above data, it can also be classified as expansive ground. Based on all the addition of stabilizers, it can be concluded that an increase in stabilizer addition, will change the soil plasticity properties from high to low. Recapitulation of stabilized soil expansion classification can be seen in table 9 .

Table 9. Recapitulation of stabilized soil expansion classification.

\begin{tabular}{|c|c|c|c|c|c|c|c|c|}
\hline \multirow[b]{2}{*}{$\begin{array}{c}\text { Stabilizer } \\
\text { Type }\end{array}$} & \multirow[b]{2}{*}{$\begin{array}{c}\text { Percentage of } \\
\text { Stabilizer } \\
(\%)\end{array}$} & \multirow[b]{2}{*}{ Ac } & \multirow[b]{2}{*}{$\begin{array}{l}\text { LL } \\
(\%)\end{array}$} & \multirow[b]{2}{*}{$\begin{array}{l}\text { IP } \\
(\%)\end{array}$} & \multicolumn{4}{|c|}{ Criteria } \\
\hline & & & & & Chen & Snethen & Seed & $\begin{array}{c}\text { SNI-03- } \\
6795- \\
2002 \\
\end{array}$ \\
\hline $\begin{array}{c}\text { Natural } \\
\text { Soil }\end{array}$ & 0 & 1,508 & 87.99 & 46.00 & $\begin{array}{l}\text { Very } \\
\text { High }\end{array}$ & $\begin{array}{l}\text { Very } \\
\text { High }\end{array}$ & High & $\begin{array}{l}\text { Very } \\
\text { High }\end{array}$ \\
\hline \multirow{5}{*}{ Salt } & 5 & 1,101 & 90,86 & 53,89 & Medium & High & Low & Medium \\
\hline & 10 & 1,082 & 58,60 & 22,34 & Medium & Medium & Low & Low \\
\hline & 15 & 0,360 & 44,00 & 15,42 & Medium & Medium & Low & Low \\
\hline & 20 & 0,378 & 42,35 & 15,23 & Medium & Low & Low & Low \\
\hline & 25 & 0,325 & 41,00 & 13,98 & Medium & Low & Low & Low \\
\hline \multirow{4}{*}{$\begin{array}{c}\text { Wood } \\
\text { Charcoal }\end{array}$} & 5 & 0.944 & 56.50 & 33.00 & Medium & Medium & Low & Medium \\
\hline & 15 & 0.704 & 53.50 & 24.63 & Medium & Medium & Low & Medium \\
\hline & 25 & 0.388 & 48.40 & 15.54 & Medium & Low & Low & Low \\
\hline & 35 & 0.338 & 45.25 & 15.20 & Medium & Low & Low & Low \\
\hline
\end{tabular}

\subsection{Mechanical parameter result and analysis}

The mechanical parameters were performed by standard Proctor test to find the optimum dry density parameter at optimum moisture content. All test results can be seen in Table 10 below. 
Table 10. Mechanical parameters test results.

\begin{tabular}{|c|c|c|c|}
\hline \multirow{3}{*}{ Stabilizer } & $\begin{array}{c}\text { Percentage } \\
\text { Stabilizer } \\
\mathbf{( \% )}\end{array}$ & $\begin{array}{c}\text { Wc opt } \\
\mathbf{( \% )}\end{array}$ & $\begin{array}{c}\boldsymbol{\gamma d} \text { Max } \\
\mathbf{( g r / c m 3 )}\end{array}$ \\
\hline Natural Soil & 0 & 28 & 1.189 \\
\hline \multirow{4}{*}{ Salt } & 5 & 26 & 1.31 \\
\cline { 2 - 4 } & 10 & 24 & 1.35 \\
\cline { 2 - 4 } & 15 & 23 & 1.425 \\
\cline { 2 - 4 } & 20 & 21.4 & 1.225 \\
\cline { 2 - 4 } & 25 & 20.8 & 1.29 \\
\hline \multirow{3}{*}{ Wood } & 5 & 24.8 & 1.038 \\
\cline { 2 - 4 } Charcoal & 15 & 34.7 & 0.978 \\
\cline { 2 - 4 } & 25 & 34.8 & 0.978 \\
\cline { 2 - 4 } & 35 & 24.7 & 0.978 \\
\hline
\end{tabular}

In general, it can be seen that when there is a rise in dry density value, the value of optimum water content will decrease. The addition of salt stabilizers makes the smaller values of optimum moisture content. The optimum dry weight becomes larger than the natural soil and appears to have a peek at a rate of $15 \%$. In charcoal stabilizers, there is an increase in water content. This has an effect on decreasing the value of optimum dry weight.

\subsection{Analysis of the best mixture selection of stabilizers}

For the selection of the best mixture, the first is based on the determination of mechanical parameters, and then the physical parameters. Soil dry weight can represent the density of a soil, therefore this parameter becomes the main determinant. Then it is followed by the determination of the increase of soil classification.

In salt stabilizers, the optimum water content (Wc opt) will decrease as an outcome to a rise in salt content. However, the optimum dry weight forms a bell pattern with a peak at the level of $15 \%$ of $1,425 \mathrm{~g} / \mathrm{cm}^{3}$. By observing the physical parameters, a $15 \%$ salt stabilizer is selected to be the best mixture. Soil classification indicates changes to Silt Low (ML) on USCS and A-4 systems on ASSHTO systems. Soil type Silt Low has a low plasticity, so it can be said that the level of soil shrinkage is not high.

In charcoal stabilizers, all percentages of the addition of stabilizer materials show lower optimum dry weight than the original soil. Therefore, the best-mixed criteria are determined by the physical parameters. Based on physical parameters, $25 \%$ of the charcoal stabilizer has been favored to be the best mixture. Soil classification shows changes to Silt Low (ML) on USCS and A-7-5 systems on ASSHTO systems. Soil type Silt Low has a low plasticity, so it can be said that the level of soil shrinkage is minimal.

Of both stabilizer materials, salt is the better stabilizer to use. This is because the highest optimum dry weight is located on a salt stabilizer of $1.425 \mathrm{gr} / \mathrm{cm} 3$. In addition, soil classification has revealed that soil has a low plasticity level, thus minimizing the expansive ground problem.

\section{Conclusion}

Based on the results of the analysis and discussion, it can be concluded that: 
- Natural soils are classified on Clay High $(\mathrm{CH})$ soil in USCS and A-7-6 systems in AASHTO system with a water content of $40.45 \%$, liquid limit (LL) $87.99 \%$, plastic limit $41.99 \%$, and plasticity index $46 \%$. Based on the percentage of pass filter 200 as much as $96.5 \%$, then the original soil is included into the fine-grained soil. High clay type soils are categorized with high plasticity, so it can be safely deduced that the soil shrink rate is high.

- Globally, it can be compared that there is a drastic decline in all parametric values. At the moisture content $(\mathrm{Wc})$, the continual addition of stabilizer content will result to a water content will decrease. A very sharp decrease in the liquid (LL) limit (LL) is seen in all stabilizer additions. The change in grain size can also be detected from the number of percentage passing filter number 200. All the addition of a stabilizer to natural soil generates a decreasing percentage of pass filter 200. The most glaring granule increase can be seen in the soil classification.

- Of both stabilizer materials, salt is the better stabilizer to use. This is because the highest optimum dry weight is located on a salt stabilizer of $1.425 \mathrm{gr} / \mathrm{cm} 3$. In addition, soil classification has shown that the soil is of low plasticity, thus reducing the expansive ground problem.

\section{References}

1. B. M. Das. (translated by N. E. Mochtar. and I. B. Mochtar). Mekanika Tanah (Prinsip - Prinsip Rekayasa Geoteknis), I, (1995)

2. Badan Standarisasi Nasional. SNI 03-6795-2002 Metode Pengujian Menentukan Tanah Ekspansif, (2002)

3. I G. A. A. I. Lestari, GaneÇ Swara, 8, 15-19, (2014)

4. M. Sangerois, Q. Wiqoyah, Renaningsih, UMS ETD-db, (2016)

5. P. H. Prasetyo, Q. Wiqoyah, Renaningsih, UMS ETD-db, (2016) 